Techne Limited, Duxford; F. J. Dent, Director of the Midland Research Station of the Gas Council, Solihull; C. A. Fleming, Chief Palaeontologist, Geological Survey of New Zealand; H. Ford, Professor of Applied Mechanics, Imperial College of Science and Technology; S. D. Garrett, Reader in Mycology, University of Cambridge; M. A. Grace, Nuclear Physics Laboratory, University of Oxford; E. J. Hanson, Medical Research Council, Biophysics Research Unit, King's College, London; A. A. C. Issigonis, Technical Director of the British Motor Corporation, Birmingham; F. E. Jones, Managing Director, Mullard Ltd.; R. U. Lemieux, Professor of Organic Chemistry, University of Alberta; I. Maddock, Controller, Ministry of Technology; N. A. Mitchison, Head of the Division of Experimental Biology, National Institute for Medical Research; J. A. C. Nicol, Plymouth Laboratory, Marine Biological Association; D. C. Phillips, Professor of Molecular Biophysics, University of Oxford; C. H. B. Priestley, Chief, Division of Meteorological Physics, Commonwealth Scientific and Industrial Research Organization; C. R. Rao, Professor of Theoretical Statistics, Calcutta; R. Riley, Plant Breeding Institute, Cambridge; M. J. Seaton, Professor of Physics, University College, London; N. Sheppard, Professor of Chemistry, University of East Anglia; D. H. Smyth, Professor of Physiology, University of Sheffield; F. Sondheimer, University of Cambridge; H. P. F. Swinnerton-Dyer, Trinity College, Cambridge; D. F. Waterhouse, Chief, Division of Entomology, Commonwealth Scientific and Industrial Research Organization; A. Williams, Professor of Geology, Belfast; R. T. Williams, Professor of Biochemistry, St. Mary's Hospital Medical School, London; J. M. Ziman, Professor of Theoretical Physics, Bristol.

\section{Automatic Medicine}

THE varied display of equipment at the International Medical Enginecring and Automation Exhibition in London last week was a measure of the extent to which the engineers are now moving in on the medical field. Medical research, even in Britain, seems to have left string and sealing wax firmly behind, and the hospitals are also taking advantage of the new methods and techniques. One popular exhibit at Medea 67 was the use of fibre light guides in such instruments as the gastroscope developed by the Atomic Weapons Research Establishment of the U.K. Atomic Energy Authority. The same principles are also being used in an instrument which can be passed into a blood. vessel to show the colour of the walls and contents, and which can thus be used to localize blood clots. Cardiac pacemakers, shown by a number of manufacturers, are typical of the miniaturized equipment now coming into service. Some of the pacemakers on show could perform such tricks as altering their pace automatically when the patient is exercising and even switching on only when the heart stops. Dialysis machines were much in evidence, and several manufacturers had something useful to show.

\section{Keeping Fruit}

Some of the farmers who attended the open day of the East Malling Research Station on Wednesday, March
15, may have needed to be reassured about the value of continuing with the research on fruit storage going on at the station. If this was so, and Dr. H. B. S. Montgomery, assistant to the director, seemed to think so when he spoke to the large group of fruit growers at the station, it is not because the research carried out so far has been a failure. The research team in the pomology unit has been able to define the conditions of storage best suited to the different types of apples and to the different requirements of the grower. It has also made some progress in finding the causes of the gradual decline in the quality of apples stored for some time. All this research has been valuable in direct cash terms to the growers, who have supported tho study by sending samples of their fruit to the laboratory for study. Because of the improvement of fruit storage resulting from the work of the laboratory, farmers no longer have to rush to market with their produce the moment it has been harvested. By a quirk of economics the results benefit not only the farmers who invest in the complex machinery required for the new methods of storage, but also those who do not have any special equipment. This mav have produced some feeling that research into storage methods is not really worthwhile. 'The research staff at the station considers, however, that it has captured the enthusiasm of farmers up and down the country and that, if it asks, it will continue to get help from these farmers.

The station is also expanding the more general aspects of its rescarch. A new electron microscope has just been installed to be used for studies of plant viruses and the fine structure of plant cells. It will have to turn to more fundamental studies of plant parasites because the experimental farm has swallowed up all the available land in the area around the laboratory.

\section{Maps by Machine}

MAPS as a means of displaying information have been caught up in what is known as the information explosion. Partly this is because the amount of information available to map makers has increased at enormous speed since the introduction of automatic data collection and logging; the next step logically seems to be automatic map drawing by computer. A one day discussion meeting on the subject of automated cartography was held on March 20 by the joint computer groups of the Institution of Electrical Engineers, the Institution of Electronic and Radio Engineers, and the British National Committee for Geography of the Royal Society.

Mr. D. P. Bickmore of the Clarendon Press at Oxford defined the need. "The first-and urgent-need is to reconstitute an existing map from digital information, automatically, and so that it conforms to traditional standards of appearance and accuracy. This will show how much hand work is still necessary, and what modifications in style, information or even accuracy should be considered". Forms of output other than lithographic printing on paper must be considered, he said; high speed plotters or cathode ray tubes may give a quick preliminary look at a map. Professor D. Linton of the University of Birmingham pointed out that only a tiny proportion of the mass of demographic and climatic information collected by govermments ever sces print in map form. Information is simply 